\title{
THE THEOLOGICAL AND PHILOSOPHICAL BACKGROUND OF BASIL OF CAESAREA'S TRINITARIAN THEORY, FOCUSING ON THE COMPARISON BETWEEN HIS WORKS AND “HIS" EP. 38*
}

There was definitely a transformation or development in Basil of Caesarea's theological teaching, especially in the Trinitarian theory. Such a maturing of his thought must naturally be affected by contemporary theological factional rivalries and supported by his understanding of ancient Greek philosophy. However, it is not necessarily easy to follow his theological development and clarify some philosophical influences on his Trinitarian theory. In order to untangle such a difficult problem, on the one hand, my article will focus on the Epistle 38 conventionally included in the edition of Basil's letters, which quite a few scholars now hold to be by Gregory of Nyssa, not Basil. ${ }^{1}$ On the

${ }^{*}$ ) A shorter version of this article was read at the Western Pacific Rim Patristics Society 3rd Annual Conference, Nanzan University, Nagoya, September 30, 2006, and its published version which is faithfully documented from it is Shigeki Tsuchinashi, Some Philosophical Influences on Basil of Caesarea's Trinitarian Theology - Concerning 'his' Epistula 38-, in: K. Demura, N. KAmimura (eds.), Patristica, supplementary vol. 2: Festschrift in Honour of Shinro Kato on His 80th Birthday (Nagoya: Shinseisha, 2006) 57-70. This article is its developed version which is close to and based on the version delivered at the Conference, but which is different from it in title and might be improved and developed in many parts (except a few overlapping in sections 3 and 4). I am grateful to John Cawte for reading and revising the manuscript closely in early drafts.

(1) Those who regard Gregory of Nyssa as the real author of Ep. 38 are R. M. Hübner, Gregor von Nyssa als Verfasser der sog. ep. 38 des Basilius in: J. Fontaine, Ch. Kannengiesser (eds.), Epekatsis (Paris, 1972) 463-490, G. C. Stead, Why Not Three Gods? in: H. R. Drobner. Ch. Klock (eds.), Studien zu Gregor von Nyssa und der christlichen Spätantike (Leiden, 1990) 149-163, L. Ayres, Nicaea and its Legacy: An Approach to Fourth-century Trinitarian Theology (Oxford-New York, 2004) 187-221, etc. On the other hand, today, the 
other hand, in comparing it with his other works and letters, I will come close to his final stage, or limit, in so far as this is possible. So in my article, firstly, some interpretations about the backgrounds of Basil's Trinitarian teaching are briefly presented. On the basis of this outline, secondly, some arguments concerning various stages of the development of his Trinitarian thought will be specifically outlined and compared. Thirdly, the argument in the main part of Epistle 38 will be analyzed in detail in order to exemplify the philosophical framework and strategy of this Cappadocian author's Trinitarian theology. Finally, some interpretations about the philosophical background of Basil's Trinitarian teaching are outlined. This article aims to cast light on some philosophical aspects of his Trinitarian thought.

\section{Some Interpretations about the Background of Basil's Trinitar- ian Thought}

The role which Basil played in fourth-century theology and ecclesiastical politics was prominent and significant, but never easy to clarify. Hence, first of all, we will consider the theological background and the development of Basil's Trinitarian thought. Needless to say, this article cannot present such an extensive overview of the Trinitarian controversy of the fourth century, and this is not its aim. For the present purpose, I think, focusing on the concept of ómoov́rtos is the key to elucidating the development of Basil's Trinitarian thought in the latter half of the fourth century. In other words, our question is: was Basil the father of the neo-Nicene or pro-Nicene theology? If so, was Basil ever a Homoiousian?

representative defender of Basil is only V. H. Drecoll, Die Entwicklung der Trinitätslehre des Basilius von Cäsarea: Sein Weg vom Homöusianer zum Neunizäner (Göttingen, 1996) 297-331. In the former part of the 20th century, for example, G. L. Prestige, God in Patristic Thought (London-Toronto, 1936) 276, believed Ep. 38 to be Basil's. In addition, as a third position, P. W. FEDwick, A Commentary of Gregory of Nyssa or the 38 ${ }^{\text {th }}$ Letter of Basil of Caesarea, OCP 44 (1978) 31-51, concludes that a decision cannot be reached on the basis of external evidence, and J. ZachHuber, Human Nature in Gregory of Nyssa - Philosophical Background \& Theological Significance (Leiden-Boston-Köln, 2000) 61-93, insists that Ep. 38 corresponds to both Basil's later works and Gregory's teaching, so-called a common "Cappadocian" position. 
According to the traditional view of Zahn ${ }^{2}$ and von Harnack, ${ }^{3} 1$ ) the

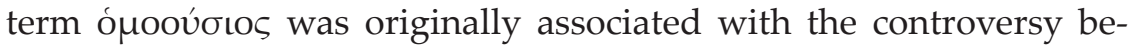
tween monarchian and pluralistic understanding of the Trinity, and 2) the "neo-Nicene" theology (neo-Nicenism) finally reinterpreted and even revoked the original, unitarian meaning of the Nicene ópoov́rıs; that is, to put it schematically, from ópoov́oros at Nicaea in 325 as

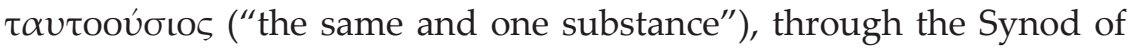

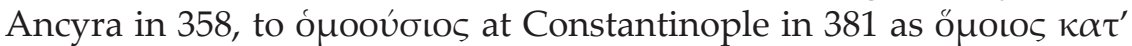
oủotáv ("like according to essence"). In this theory, the father of the neo-Nicene theology is Basil of Ancyra, as the leader of the Homoiousians, and not Athanasius nor Basil of Caesarea.

However, this theory is no longer held (of course, not unanimously, except in Germany, at least). Firstly, in the 350s, the existence of a party which independently can be called Nicene is extremely questionable. In the Synod of Antioch in 341, Athanasius, an advocate of the Nicene homoousion, was deposed, and those who supported its creed "probably found both Arius' language and the Athanasian/Marcellan theology unacceptable." ${ }^{4}$ Homoousian (essence)-terminology disappeared from the forefront of history, and then homoiousian (likeness)-terminology assumed a central position. Therefore, secondly, it is impossible for Homoiousians, like Basil of Ancyra, to react against the Nicene homoousion which had already been repealed. According to recent research, those who prominently rose into power in the latter half of the 350s are the "Homoians," that is a pro-subordinationist group. They insisted that "the Son is 'like' (homoios) the Father although distinct and ontologically inferior." ${ }^{5}$ Among them, especially, Aetius and his disciple Eunomius led the most subordinationist faction and were called "Anomoians," because they argued that the Father and the Son were "unlike" (anomoioi) according to essence. In contrast to them, the other bishops, who thought of the Son as "like the Father according to essence" and were thereby called "Homoiousians," were hostile to the Anomoians and gathered around Basil of Ancyra to promulgate

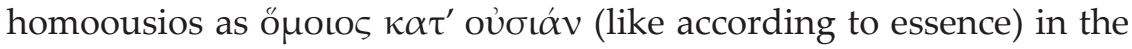
358 Synod at Ancyra. They were, however, deposed by radical Ho-

(2) Th. ZAHN, Marcellus von Ancyra (Gotha, 1867) 8-32.

(3) A. von Harnack, N. Buchanan (trans.), History of Dogma, vol. 4 (New York, 1958).

(4) Ayres, Nicaea and its Legacy..., 432.

(5) Ibid. 
moians in the Synod at Constantinople as early as 360. According to an Anomoian's report, 6 possibly, Basil of Caesarea might have also attended this Synod, solicited by Eustathius of Sebaste. In addition, he seems "to have had some personal connection with Basil of Ancyra and he was strongly opposed to the 360 Homoian Creed." 7 Therefore, traditionally, he has been regarded as a Homoiousian. But the case is much more complicated.

What we should draw attention to here first of all is the existence of the neo-Nicene party headed by Meletius of Antioch. Those neoNicenes, the Meletians, were regarded as schematized from Homoians, not breakaway Homoiousians. So, in the 360 Homoian Synod, their bishops replaced deposed Homoiousians, for example, Meletius replaced Eustathius of Antioch, and Athanasius of Ancyra replaced Basil of Ancyra. At least, in the judgment of another Nicene group led by Paulinus in Antioch, Meletius appeared to be put in office by "Arians." As a result, there was fierce hostility between the Meletians and Homoiousians. After that, Meletius was exiled to Armenia, and moved closer towards approving Nicene homoousios. ${ }^{8}$ Consequently, Basil of Caesarea probably managed to maintain his association with both camps. If this were the case, was Basil a Homoiousian or not?

\section{Comparison between Basil's Ep. 236, 361 and AE II.4}

Fortunately, in his early correspondence (Ep. 361) with Apollinarius of Laodicea (dated about 360-361), we may gain insight into his real intention about Homoiousianism. The central part of the letter is:

For we have supposed that whatever by way of hypothesis the substance (ovं $\sigma i \alpha$ ) of the Father is assumed to be, this must by all means be assumed as also that of the Son. So that if anyone should speak of

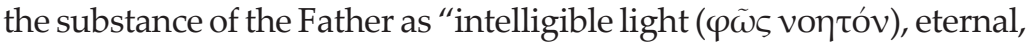
unbegotten," he would also call the substance of the Only-begotten "intelligible light, eternal, unbegotten." And in such a meaning the

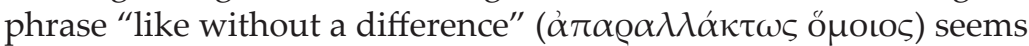

(6) This anomoian is Philostorgius. Cf. Eusebius of Caesarea, Historia ecclesiastica, ed. SchwARTz, GCS 9, IV 12.

(7) Ayres, Nicaea and its Legacy..., 188f. According to R. P. C. Hanson, Basil "was alienated from Dianius because the latter had signed the Creed of Constantinople" (R. P. C. Hanson, The Search for the Christian Doctrine of God: The Arian Controversy 318-381 AD (Edinburgh, 1988) 680).

(8) Cf. H. Chadwick, The Church in Ancient Society - From Galilee to Gregory the Great (Oxford, 2001) 292-294, 344-347. 


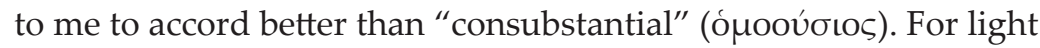
which has no difference from light in the matter of greater and less cannot be the same - because each is in its own circumscription of

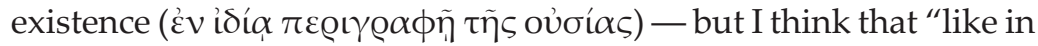

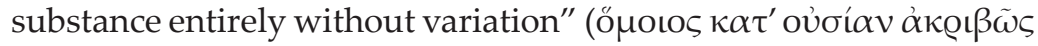
$\dot{\alpha} \pi \alpha \varrho \alpha \lambda \lambda \alpha \dot{\kappa} \kappa \tau \omega \varsigma)$ could be said correctly. ${ }^{9}$

In this quotation, we can certainly find the homoiousian phrase

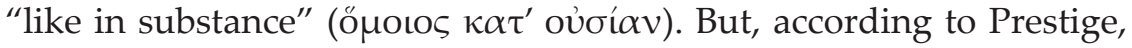
Basil's position here is fully Athanasian taken in connection with Ep.9, and the phrase "like in substance entirely without variation" amounts to the same thing as the homoousion. ${ }^{10}$ On the other hand, according to Zachhuber's new elucidation, Basil's argument here seems to reject both the homoiousian approach and Athanasius' homoousian view, because it "is not his generation from the Father that accounts for the Son's divinity in the first place, but the community of logoi: whatever can be said of the Father qua substance holds equally good for the Son too." ${ }^{11}$ Whichever interpretation we follow, Basil's standpoint seems to be not simply homoiousian. What is more, he has not yet determinately elucidated a unity between the Father and the Son, or the personal distinction of Father, Son, and Spirit, either. In this regard, Basil's theology in these early years is obviously immature.

We will, then, turn to his Adversus Eunomium I and II dated about 363 or 364. In this phase of the development of his Trinitarian thought,

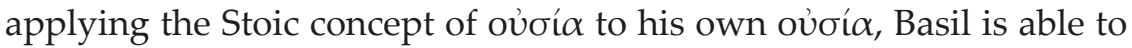
logically ground the unity of the three hypostases on the unity of substance. For instance, in $A E$ II, 14, ll.1-20:

Yet, to this argument, who in his right mind would add, that they whose names are distinct, must necessarily differ also in their sub-

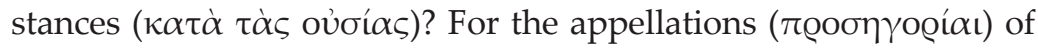
Peter and Paul and all persons in general are distinct, yet the substance of all is one. Hence we are identical to each other in most things; only

(9) R. J. Defferrari (tr.), Basil. Letters, vol. 4 (Cambridge, MA, 1950) 335. Translations of all letters are taken (with some minor changes) from Defferrari's edition.

(10) G. L. Prestige, St Basil the Great and Apollinaris (London, 1956) 18. Additionally, the author insists that in the de Spritu sancto (45) "the real meaning of the monarchy was seen in a unity of ousia, though he [Basil] does not

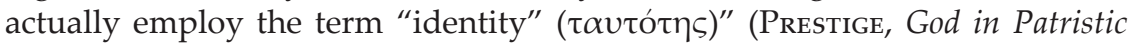
Thought, 230).

(11) ZACHHUBer, Human Nature in Gregory of Nyssa..., 53. 


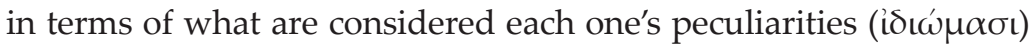
have we been made different one from the other. It follows that the appellations signify not the substances, but the properties which characterize ( $\chi \alpha \varrho \alpha \kappa \tau \eta \emptyset i \zeta o v \sigma \iota v)$ each one. So that when we hear "Peter," we do not grasp (vooṽ $\mu \varepsilon v)$ his substance by means of his name (I here

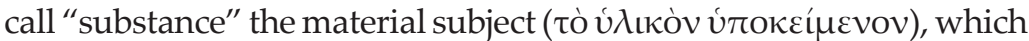
the name does not in the least signify), but we register the concept

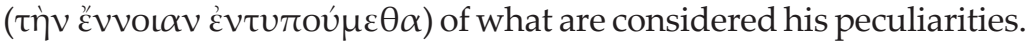
... So that the name, on the one hand, demarcates ( $\dot{\alpha} \varphi$ opí $\left._{\varepsilon l}\right)$ for us the character ( $\chi \alpha \varrho \alpha \kappa \tau \eta ்)$ of Peter, but, on the other hand, it in no

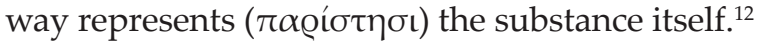

In his early treatise, Ep. 361, Basil has often used oủoí $\alpha$ for particular substance. As a result of such an understanding, he has been faced with a dilemma concerning substance: if no substance can exist without its being in any person, the undivided divine substance subsists dividedly in each of three divine persons. Therefore, against the Neo-Arian who insisted on a distinction between the substance of the Father and of the Son, Basil had to shift the emphasis from particular to common oúrí $\alpha$. In the quotation above, then, he finds a solution to these difficulties in the Stoic concept of oúrí $\alpha$ as an indefinite substra-

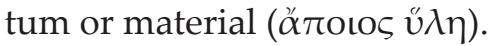

However, in Ep. 236 dated 376, late in his life, Basil has recourse to the Aristotelian distinction between koเvóv and ísıv.

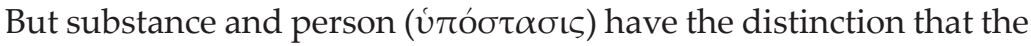

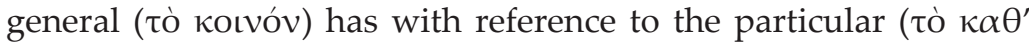

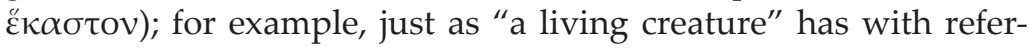
ence to "a particular man ( we confess one substance for the Godhead, so as not to hand down

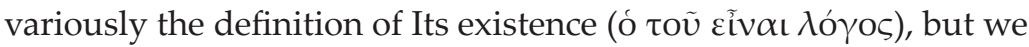

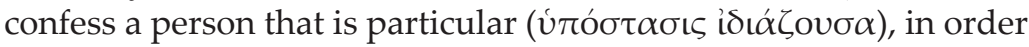
that our conception ( $\varepsilon v v o t \alpha$ ) of Father and Son and Holy Spirit may be for us unconfused and plain.

... Therefore, we must add the particular to the general and thus confess the faith; the Godhead is something general, the paternity something particular, and combining these we should say: "I believe in God the Son."13

(12) Translation is that of P. Kalligas, Basil of Caesarea on the Semantics of Proper Names, in: K. Ierodiakonou (ed.), Byzantine Philosophy and its Ancient Sources (Oxford, 2004) 42).

(13) DefFerrari, Basil. Letters..., 401, 403. 
If, here, the distinction between 'ísıv and koเvóv might be understood as the Aristotelian distinction between concrete particular existence (the primary substance) and common species (the secondary substance), a divine unitary shared nature would be not any essential principle, but an abstract and nominalistic universal. Can we find out any suggestion to ease this concern about "the Aristotelian route"? My answer is "yes." So, let us explore that possibility, closely and specifically analyzing Ep. 38, in the following section.

\section{Philosophical Structure of Ep. 38}

The reason this letter was written was that there was a tendency at

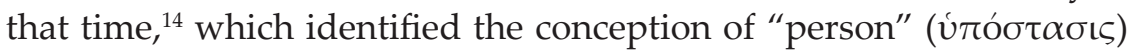
with that of "substance" (ovoí $\alpha$ ). Many arguments over the doctrine of the Trinity "fail to discover any difference between the general conception of substance (

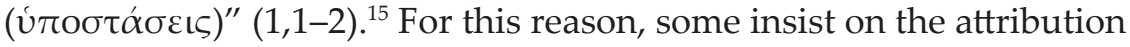
of one person ( $\mu$ í $\alpha$ vं ó $\tau \tau \alpha \sigma \iota \varsigma)$ to God; and others, vice versa, insist on the division of the substances (oúoí $\alpha$ ) into three.

Hence in this section, we shall focus especially on the following development: from [1] the distinction between the proper and uni-

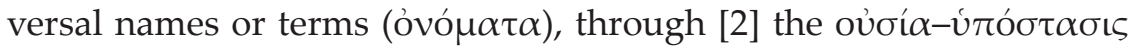
distinction, finally to [3] its application to the theory of Trinity. The point here is the identification of the relationship between koเvóv and

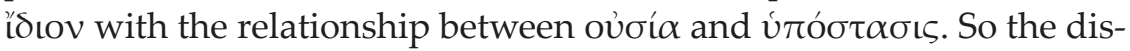
tinction of a universal concept from an individual concept is explained on the basis of the distinction of the species of "man" from individual men, such as Paul, Silvanus, and Timothy.

(14) According to Hübner (HüBnER, Gregor von Nyssa..., 490), Ep. 38 was written by Gregory in 379-380, shortly before the Council of Constantinople. On the other hand, according to Drecoll (Drecoll, Die Entwicklung..., 324), it was written by Basil between 375 and 379, the year when he died, on the basis of the date of Ep. 236 and Ep. 214.

(15) In the following, references in the text will be to section and line of Courtonne's edition (E. Y. Courtonne, Saint Basile, Lettres, 3 vols. (Paris, 1957-1966). 


\subsection{The Distinction between Proper and Universal Names (Terms)}

According to the Cappadocian author's semantic theory, ${ }_{1}^{16}$ all names (ovó $\mu \alpha \tau \alpha$ ) are divided into the following two classifications:

a) universal names, "which are predicated $(\lambda \varepsilon \gamma$ ó $\mu \varepsilon v \alpha)$ of subjects plural and numerically diverse, have a more general meaning

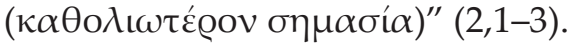

b) "other proper names have a very specific denotation

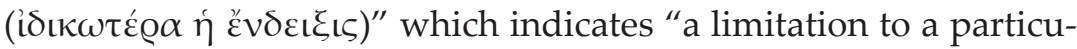
lar thing ( $\pi \varepsilon \varrho \iota \gamma \varrho \alpha \phi \eta)$," "so far as the individuality of the object is

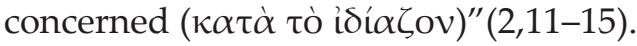

We can take as an example, "man." "When you say 'man,' you

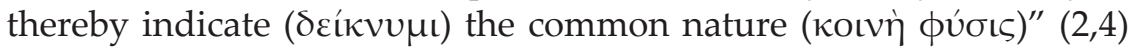
in distinction from individual men. It is by means of "a further note

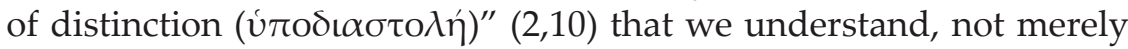
man in general, but "Peter" or "John" in particular.

Now, we should notice that both proper names and universal names have a dual function: reference and signification. It seems clear that the proper name indicates a concrete thing $(\pi \varrho \tilde{\alpha} \gamma \mu \alpha)$ in a deictic way, but, at the same time, it has another function to convey the notion ( $\varepsilon^{\prime} \mu \phi \alpha \sigma \iota \varsigma$ / $\left.\varepsilon^{\prime} v v o t \alpha\right)$ of individual things. In other words, the proper name signifies characteristic properties or peculiar notes

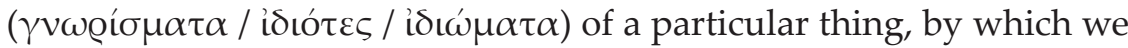
can differentiate it from others and identify it. On the other hand, the universal name not only has a deictic function to indicate the common nature ( $\phi v ́ \sigma \iota \varsigma)$ as mentioned before, but also signifies common properties of all the individuals which we could call by the name. To put it

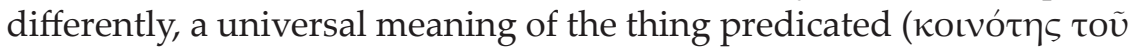

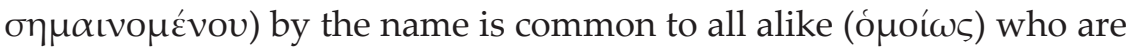
included under the same name (2,8-9). The question we have to ask here is: what entity does the proper term's signification correspond to? What entity does the universal term's reference correspond to? The

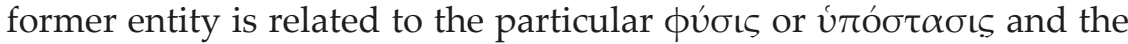

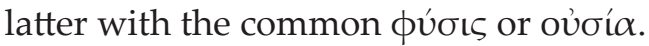

(16) For an attempt to find out the modern and creative idea in Basil's semantics of proper names, cf. Kalligas, Basil of Caesarea..., 31-48. 


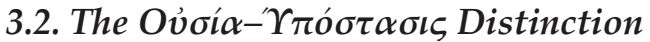

What is at the core of the understanding of the difference between

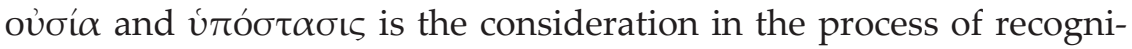
tion, as below:

Someone who says "man" causes in a hearer's mind "a sort of vague

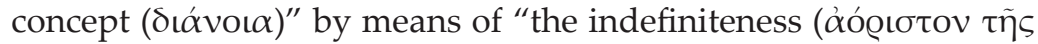

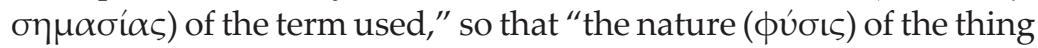
is indicated by the name (óvor $\alpha$ )," but "the thing which subsists

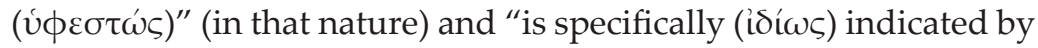

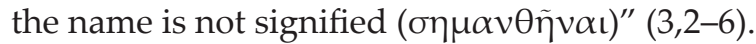

On the other hand, someone who says "Paul" designates the nature

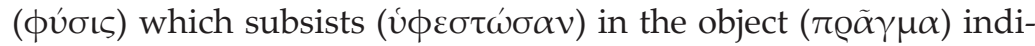
cated by the name $(3,6-8)$. It seems clear that this particular nature is a hypostasis.

First of all, what should be noticed is that only in 2,1-19 and 3,1-8, the author uses a pair of terms: name (óvo $\mu \alpha$ ) and nature ( $\phi v ́ \sigma \iota \varsigma)$. Before and after those lines in this context, however, he uses another

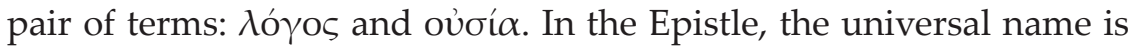
never used to indicate oú $\sigma$ í $\alpha$. With such a usage of terms, I think, the author deliberately develops an argument in a subtle way such that we can distinguish between the semantic or ordinary language level and the metaphysical or analytical knowledge level. This method, that is, a transition from a kind of vague whole which is more knowable

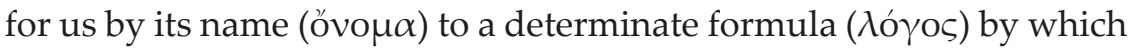
principles become known to us, seems to be very similar to the Aristotelian method of physics. ${ }^{17}$ In the following, I would like to elucidate a shift from a semantic stage of the relationship between övo $\alpha$ and $\phi v ́ \sigma \iota \varsigma$ to a metaphysical stage of the relationship between $\lambda o ́ \gamma 0 \varsigma$ and

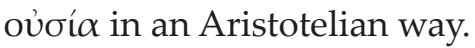

Firstly, although the common nature ( $\phi \dot{\sigma} \sigma \varsigma)$ is indicated ( $\delta \eta \lambda \omega-$ $\theta \tilde{\eta} v \alpha \iota)$ by the name, such as "man," vaguely $(3,4-5)$, in the case of

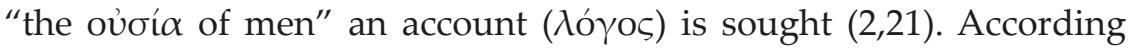
to the previously mentioned Aristotelian method, the common nature

(17) Cf. Aristotle, Physica A1, 184a10-b14, esp., 184a21-b10: "Now what is to us plain and obvious at first is rather confused masses, the elements and principles of which become known to us later by analysis. Thus we must advance from generalities to particulars; for it is a whole that is best known to sense-perception, and a generality is a kind of whole, comprehending many things within it, like parts. Much the same thing happens in the relation of the

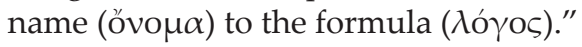


which the name shows or indicates, but does not signify, is some sort of whole. Aristotle says, "a name, e.g. 'round,' means vaguely a sort of whole; its $\lambda$ ó $\gamma 0 \varsigma$ analyzes this into its particular senses."18 Therefore, universal or common $\phi u ́ \sigma ı \varsigma$ is, I should contend, humankind as sort of whole including its individuals, ${ }^{19}$ such as Paul and John. Someone who says "man" can, for example, enumerate Paul and John as a man, but he does not know its principle or essence which causes something to be a man. It is oứí $\alpha$ that causes something to be a man, and it is

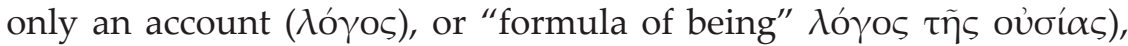
that can describe oúrí $\alpha$.

Now that we have elucidated what oúoí $\alpha$ is, we will be able to understand how the philosophical framework that has been observed so far is used to define the most important key word, homoousion, in the Nicene creed. In the Epistle the author writes:

Whatever accounts ( $\lambda$ ó $\gamma \mathrm{ol}$ ) show the substance of Paul will apply to the other men as well. Those who are described with the same "for-

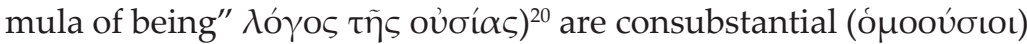
with one another" (2,24-26).

The substance (ov́rí $\alpha$ ) in this context is neither the individual like the thing $(\pi \varrho \tilde{\alpha} \gamma \mu \alpha)$ pointed out by proper names, nor the common $\phi v$ oıs as a sort of whole indicated by universal names, but a principle or essence by which all men are caused to be a man "in the same way

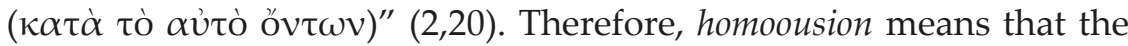
individuals have the same cause and essence, and are made to exist in the same way.

Secondly, when someone uses the proper name (óvo $\mu \alpha$ ) to refer to the individual thing $(\pi \varrho \tilde{\alpha} \gamma \mu \alpha)$, the author says that he designates the particular nature ( $\phi \dot{v} \sigma \iota \varsigma)$ subsisting in that thing. In that case, what kind of entity does that particular $\phi v ́ \sigma \iota \varsigma$ correspond to? It is, I think, some sort of whole in each individual, which corresponds to a bundle

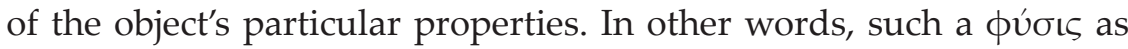
some kind of whole or integrity in the thing is the necessary condition of the possibility for anyone to indicate the individual thing, such as

(18) Aristotle, Physica A1, 184b11-12.

(19) Cf. ZAChHuber, Human Nature in Gregory of Nyssa..., 61-93. Although the argument of my interpretation is different from the one that he espouses, our conclusions are rather similar.

(20) This phrasing is Aristotelian. Translation is given according to Zachhuber (cf. ZaChHUBer, Human Nature in Gregory of Nyssa..., 71). 


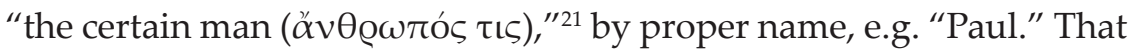
person who can only designate the individual as "Paul," however, knows nothing yet about what is the nature, or what causes him to be that individual. At this phase, the author first proposes his new thesis: "that which is specifically ( $i \delta i \omega \varsigma$ ) referred to is indicated by the expres-

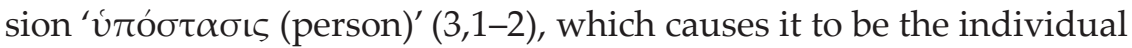
or is 'the principle of individuation.'" 22 It should be noticed here that the oúrí $\alpha$ could not actually exist without being individualized by the

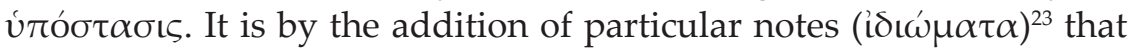
the conception of substance regarded as indeterminate leads to the recognition of concrete things. At the same time, however, the indi-

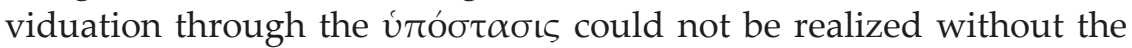
oứí $\alpha$ as a universal essence to be individualized. It is significant that both are complementary.

\subsection{The Application to the Theory of the Trinity}

So far we have found our author 1) developing an argument con-

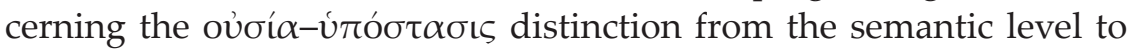
the metaphysical level, and 2) emphasising the distinction between the unifying and causing ousia and individualizing hypostasis. In this phase of the argument, he transfers the philosophical framework and the principle of the differentiation in the aforesaid speculation to " $\mathrm{di}$ -

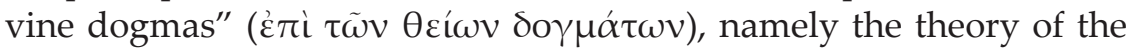
Trinity.

What should not be overlooked here is that oúrí $\alpha$ in God the Father, the Son, and the Holy Spirit cannot be described, for example, as "God," just as the universal name, e.g., "man," cannot describe oúoí $\alpha$

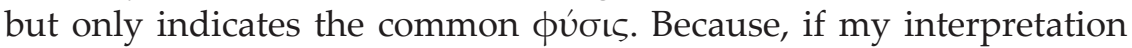

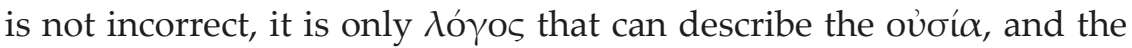
oúoí $\alpha$ in itself is not God as a $\pi \varrho \tilde{\alpha} \gamma \mu \alpha$, but the cause of their being God. ${ }^{24}$ Therefore, the oúrí $\alpha$-concept in the theological context can-

(21) Cf. Ep. 38, 3,14-17. In this quotation from Job 1:1-2, Job is mentioned

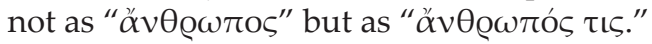

(22) ZACHHuber, Human Nature in Gregory of Nyssa..., 78.

(23) For example, "the name, the place," ... and "the marks which reveal his character, and all such external adjuncts as will differentiate him" (3,19-25).

(24) In this regard, however, "the author" explicitly emphasizes that our mind cannot depend upon "a definitely prescribed conception (vó $\mu \alpha)$ "

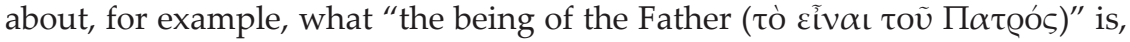
[sc. the oúcí $\alpha$ of the Father], because "we are sure that it is beyond all concep- 
not be translated as "God," otherwise either unitarianism or tritheism would be introduced. ${ }^{25}$

Keeping this in mind, then, what we have to confront is a sort of dilemma as below. On the one hand, the three Persons subsist as individuals. On the other hand, three Persons are, however, still unified and homoousioi, namely, one as nature and substance. So, if no substance can exist without its being in any hypostasis, it would be a sort of paradox to maintain that the divine substance subsists in its own hypostasis. Because the undivided substance would subsist in three hypostases, that is, should have been already divided into three. This paradox, which is expressed in the Epistle using a double oxymoron as "united separation and disunited connection," will be solved by the author, 1) through an illustration of the rainbow, ${ }^{26}$ 2) through exemplifications from the Scriptures and their exegeses, ${ }^{27}$ and 3) implicitly through his philosophical strategy. In this article, the third solution is the most important. That is, just as (1) there should be, on the semantic level, the complementarity or interdependency between universal signification and particular reference, and (2) on the metaphysical

tion" (3,33-36). However, on the other hand, the author merely and without any arguments presupposes that "the same account of Being Uncreated and

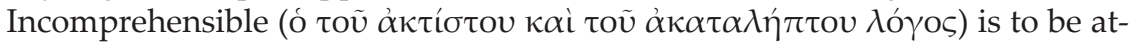
tributed to the Father, to the Son, and to the Holy Ghost" (3,38-40).

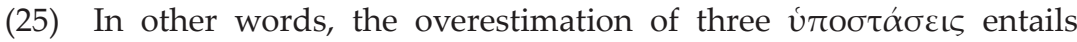
tritheism, on the other hand, the overemphasis on the one ovoí $\alpha$ brings about unitarianism. In the latter case, rejection of the individuality of the Son or the Holy Spirit brings about Sabellianism, and denial of the deity of the Son entails subordinationism.

(26) For a natural scientists' explanations of the rainbow which Basil seems to borrow, cf. Diogenes Laertius, Vitae VII, $152 \mathrm{f}=$ Poseidonius, Frgm. 335. According to the epistle (section 5), that "which is disunited and at the same time connected" in the Holy Trinity can be explicated "by analogy from things which appear to our sense-perceptions," for example, the brilliancy of

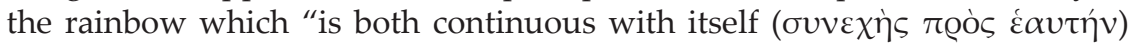

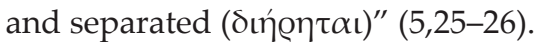

(27) For example, the author refutes the wrong Christology based on Hebr.

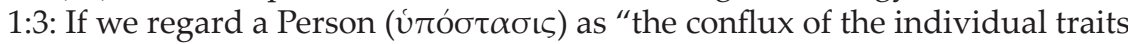

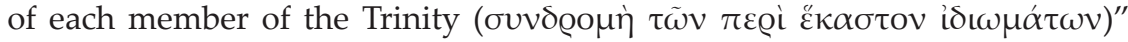
$(6,5-6)$, then "the Son has been formed by the individual traits $\left(\gamma \nu \omega \omega^{\prime} \sigma \mu \alpha \tau \alpha\right)$ of the Father" and "there no longer remains to the Father exclusively to be called 'unbegotten ( $\dot{\alpha} \gamma \varepsilon v \nu \eta \dot{\tau} \omega \varsigma$ عĩval)' in a sense peculiar to Himself alone" $(6,16-17)$. 
level, the complementarity between essence and individuality, so we should also find out, (3) on the theological level, the interdependency

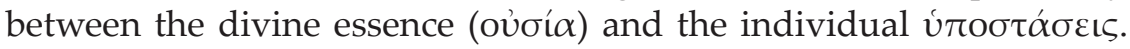

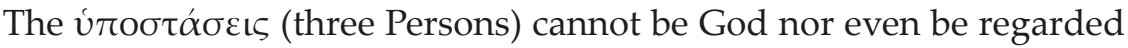
as God without the ovoí $\alpha$, and, at the same time, the latter could not exist actually without the former.

To put it specifically, the unifying relationship among three Persons is eventually developed as below.

1) "Every blessing ( $\alpha \gamma \alpha \theta$ óv) which is bestowed on us by power divine" is ascribed to "the working of the Grace ( Apostle says (1 Cor. 12:11). (4,2-4)

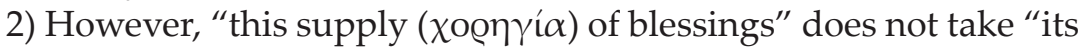
origin" from the Holy Spirit alone, but are brought about by the Only-

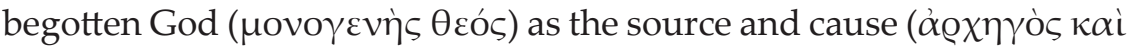
$\alpha$ ít เov) through the Spirit (4,6-8). Additionally, in response to John 1:3, "all things were made by Him [the Son] and in Him cohere" (4,11-13). By the power of the Son "all things are brought into being from nonbeing" (4,15-17).

3) However, additionally, not "even by this power without a beginning ( $\alpha \dot{\alpha} \propto \chi \varrho \omega \varsigma), "$ but "there is a power which exists without genera-

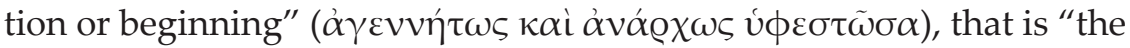

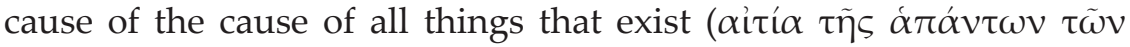

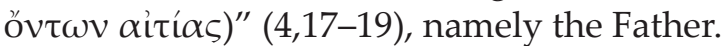

4) At the same time, "it is impossible for a man, if he has not been previously enlightened by the Spirit, to arrive at a conception of the Son" (4,21-22).

\section{Some Interpretations about the Background of Basil's Trinitar- ian Thought}

We have outlined the development of Basil's Trinitarian thought, and, by closely analyzing Ep. 38 in comparison with his other works before it, have come close to his final stage, if this letter is his, or, if not, we have reached his limit. It may be promising, then, to proceed to the discussion about its philosophical background, in order to get a key to the understanding of the intricate argument. Indeed, many previous researchers have given various interpretations in regard to the question of the doctrines which lead the underlying Epistle's argument: among Platonic, Aristotelian, and Stoic doctrines, which plays a leading role? And the point here is, I think, how its concept of oúoía should be interpreted. 


\section{(1) The Platonic Background}

In the fourth century, generally, some sort of Platonism was pervasive and assumed among the Cappadocian Fathers, but, all the more, its influence beyond such general assumptions has proved very difficult to exemplify. For Basil, according to Rist, "there is not a trace of the influence of Neoplatonic speculation in that area of Trinitarian theology from which the Council [of Nicaea] had excluded Platonism forever." ${ }^{28}$ Nevertheless, some scholars ${ }^{29}$ insist that Basil's concept of common oúrí $\alpha$ as the underlying substratum is due to the influence of the Platonic understanding of universals, which have ontological priority over and are independent from particular things. Such a concept of the "common stuff," however, appears to be rather Stoic, not Platonic, and such a view of the universal is also manifestly ascribed to Gregory of Nyssa. ${ }^{30}$ At least, the author of the Epistle 38, whether Basil or Gregory, does not develop an argument about the ontological priority and independency of the universal ovoí $\alpha$; indeed, that would be against his intention in the Epistle. Therefore, we need not ponder over the question of the Platonic background here.

\section{(2) The Stoic Background}

It has been made clear by the research ${ }^{31}$ done during the last century, especially since Hübner, ${ }^{32}$ that Stoic thought, particularly the logic and physics of the Stoics, permeate the thoughts of and play a central role in Basil and his younger brother Gregory of Nyssa, whether in their cosmology or their theology. Thus, in order to find a solution to the trinitarian difficulty mentioned above, Basil has recourse to Stoicism.

According to Stoicism, concrete individuals consist of an indefinite

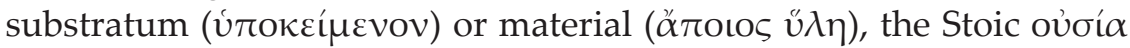

(28) J. M. Rist, Basil's "Neoplatonism". Its Background and Nature, in: J. P. Fedwick (ed.), Basil of Caesarea. Christian, Humanist, Ascetic, vol. 1 (Toronto, 1981) 220.

(29) J. Lebon, Le sort du "consubstantial" nicéen, in: RHE 48 (1953) 641657; A. M. Ritter, Das Konzil von Konstantinopel und sein Symbol. Studien zur Geschichte und Theologie des 2. Ökumenischen Konzils (Göttingen, 1965) 286-291.

(30) Cf. D. L. BALÁs, The Unity of Human Nature in Basil's and Gregory of Nyssa's Polemics against Eunomius, SP 14.3 (1976) 275-281.

(31) A. Grillmeier, Christ in Christian Tradition (London, ${ }^{21975) ~ 367-377 ; ~}$ R. G. TANnER, Stoic Influence on the Logic of St. Gregory of Nyssa, SP 18.3 (1989) 557-584.

(32) HüBNER, Gregor von Nyssa... 
as the first category, and qualities as the second category which are

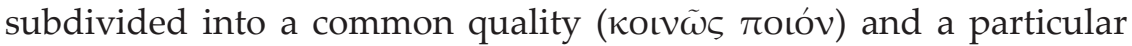

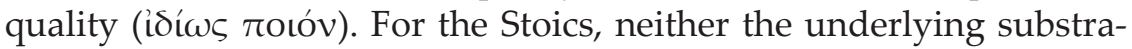
tum nor the common qualities exist taken by themselves. Applying the

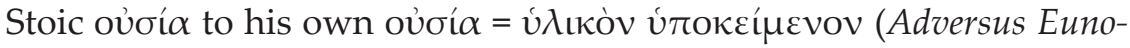
mium I.15, ll. 30-35; II.4, ll. 3-13), Basil can logically ground the unity of the three hypostases on the unity of substance.

Drecoll, however, criticises the fact that Basil's distinction between Koเvóv and 'írov does not correspond with the Stoic contrast between

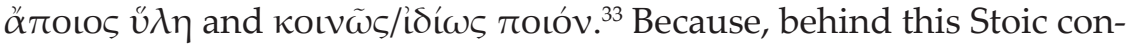

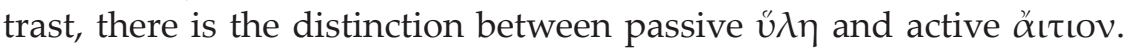

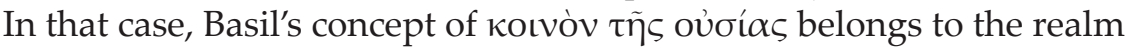

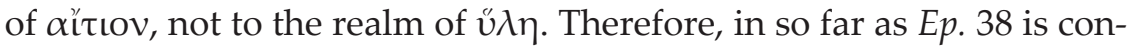
cerned, the concept of ovorí $\alpha$ cannot be interpreted as the indefinite substratum in the Stoic way, though, as a whole, the Stoic influence upon Basil's Trinitarian thought is undeniable.

(3) The Aristotelian Background

In terms of the distinction between kotvóv and iotov in the present Epistle, its author insists that the individual cognitive note ( $\gamma \nu \omega$ Qí $\sigma \mu \alpha \tau \alpha)$ must be added to the indefinite concept of oú $\sigma i \alpha$ in order to recognize concrete individuals. According to Drecoll, this insistence suggests the Peripatetic background, especially the Aristotelian analysis of a definition in Topica, and Hübner also clearly emphasizes its similarity to Aristotle's Categories and De Interpretatione.

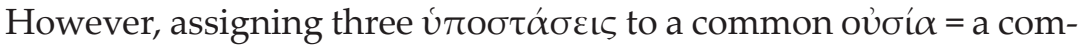

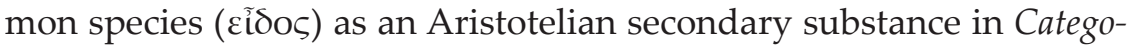
ries and thus maintaining unity as members of a species, that is, taking the so-called "Aristotelian route," falls short of the more promising theory of the Trinity. Because, "the identification of the second substance in Categories" as an abstract and nominalistic universal "with the eidos of the central books of Metaphysics" is obviously questionable, unless an argument mediating between the two is developed in the way we interpreted it in 3.2. In addition, we need to balance "the input from Stoic logic with Aristotelian elements mediated by later philosophical sources," ${ }^{\prime 3}$ as seen in the following.

(33) Cf. Drecoll, Die Entwicklung..., 319.

(34) D. G. Robertson, Stoic and Aristotelian Notions of Substance in Basil of Caesarea, VC 52 (1998) 394. 
(4) The Synthetic or Eclectic Background in Late Ancient Philosophy

Finally, in contrast with the aforesaid approach, neither one particular author nor one particular school of thought, but late ancient synthetic interpreting developments of Aristotle's philosophy, which have to take into account some strand of non-Aristotelianism, need to be focused on. In particular, what needs to be noticed is a tendency to substitute the Aristotelian terminology for Stoic terminology in the logical realm from the late second century on. As a result, the view of Ep. 38 also cannot avoid becoming some kind of synthesis of the two theories; the Aristotelian and the Stoic. According to Zachhuber, on the one hand, the author holds names to indicate things ( $\pi \varrho \alpha ́ \gamma \mu \alpha \tau \alpha)$ in accordance with the Aristotelian theory. On the other hand, "the Stoic doctrine, too, seems to have left its traces in the Epistle 38 in so far as it recognises a relation of the names to universal and particular elements." ${ }^{35}$ Additionally, the Platonic and Peripatetic concept of incorporeal forms combined with the Stoic notion of corporeal qualities, allows us finally to find the conception of the universal or the common oú ${ }^{\prime} \alpha$ (the secondary substance in Aristotelian meaning) as the whole composed of the primary substances as its parts. ${ }^{36}$

This attractive interpretation is exemplified by several texts, for example, Categories (ch. 5, 2a14-17), De Interpretatione (ch. 7, 17a38-17b1), Porphyry's Isagoge (7,27-8,4), and Boethius' commentary (in de Int., II,7). And it is also in part similar to my interpretation. Concerning the authorship of Ep. 38, however, Zachhuber's insistence that the Epistle should be treated as documenting "the Cappadocian" teaching, neither Basilian nor Gregorian respectively, but collectively, ${ }^{37}$ is unacceptable, because the concept of a "Cappadocian" position with little difference overestimates a common tradition in Cappadocians, and "blurs important differences" 38 among them. In other words, the expression of "the Cappadocian author of the Epistle 38" is a rightly cautious reservation to avoid a clear-cut decision, but, at the same time, can also suggest abandonment of further investigation into the truth.

(35) ZaCHHuber, Human Nature in Gregory of Nyssa..., $82 \mathrm{f}$.

(36) Ibid., passim, esp. 83, 89.

(37) Ibid., 63. Zachhuber insists that "it does not appear that there is a clear-cut distinction to be made between Basil's and Gregory's approaches to the ousia-hupostasis distinction and the understanding of the homoousion" (ibid., 61).

(38) Ayres, Nicaea and its Legacy..., 205, n. 60. 


\section{Epilogue}

As the Stoic influence upon Basil is undeniable (as seen in 4), if the author regards the common ousia not as the indeterminate substratum in the Stoic way, but as the universal species in the Aristotelian way in the Epistle 38, then he is not Basil, but Gregory of Nyssa. However, this contrast between Basil and Gregory by means of a differentiation among philosophical backgrounds is somewhat schematically oversimplified. Both Basil and the author of the Epistle are more flexible and complicated, not only philosophically, but also theologically (as seen in 1). In other words, whether the real author of Ep. 38 is Basil or Gregory, I am convinced that clarifying this letter's argument could cast light on some philosophical aspects of Basil's Trinitarian thought. Now that we have given a general overview of the development of his theology, we can finally say with certainty that Basil was one of the fathers of pro-Nicene theology, no more and no less.

\section{SUMMARY}

In my article, some interpretations about the backgrounds of Basil's Trinitarian teaching are briefly presented. On the basis of this outline, some arguments on various stages of the development of his Trinitarian thought will be specifically outlined and compared. Then the argument in the main part of Epistle 38 will be analyzed in detail in order to exemplify the philosophical framework and strategy of this Cappadocian author's Trinitarian theology. Finally, some interpretations about the philosophical backgrounds of Basil's Trinitarian teaching are outlined. In the course of this argument, the article aims to cast light on some philosophical aspects of his Trinitarian thought. 